\section{UDC 378.091.011.3-051:811.111]:159.955 \\ DOI https://doi.org/10.32840/1992-5786.2020.71-2.38}

\author{
T. S. Rozumna \\ Candidate of Pedagogical Sciences, \\ Associate Professor at the Department of Foreign Languages and Teaching Methods \\ Berdiansk State Pedagogical University
}

\title{
TEACHING CRITICAL THINKING FUTURE ENGLISH TEACHERS
}

The articles deals with the issue of teaching critical thinking future English teachers. The main purpose of this work is to analyze effectiveness of critical thinking in training future English teachers and to define basic stages and techniques that help to form students' critical thinking. There are two points of view on teaching critical thinking in the English classroom. Some teachers believe critical thinking is a result of schooling in students' native language, the others think that foreign language helps to develop critical thinking skills. The author's idea is that well-designed communicative language classes help to develop these skills by comparing and contrasting cultures, discussing cause and effect of social events in the world, problems of current interest. It is pointed out that critical thinking is hard, and teachers should pay special attention to the formation of it.

The formation of critical thinking skills consists of three stages. They are challenge, comprehension, reflexion. On each stage different techniques can be used. On challenge stage such techniques as brainstorming, thin/thick questions or KWL chart can be used. On comprehension stage the author uses the "Six Hats" method and on the reflexion the future English teachers writes poems "Cinquain". In order to activate students' critical thinking skills, English teachers need to present alternatives, different ways of interpreting texts and different conceptions of the world. It is also should mention, that critical thinking can be developed at any part of the lesson. For example, the technique "Corners" help to develop critical thinking using all four skills (reading, listening, writing and speaking).

Introduction of critical thinking provides a transition from learning, focused mainly on memorization, to learning aimed at developing independent conscious thinking of students, helps to prepare students for life in an information society, choose the truth among the constant flow of information, critically check the information, cooperate with others.

Key words: critical thinking, future English teachers, interactive methods of teaching, stages, techniques.

Formulation of the problem. Modern society requires the education of independent, proactive, responsible citizens, able to interact effectively in social, industrial and economic areas, which requires the development of personal qualities and creative abilities, the ability to acquire independently new knowledge and solve problems. The main task of university education is to prepare a competent specialist who will be able to find the right solutions in specific educational, future professional and life situations. The process of integration of Ukrainian education into the European educational space increases the importance of learning a foreign language not only as an academic discipline, but as a means of mastering skills and abilities of foreign language communication.

Our world is a world of information that is rapidly increasing, as well as rapidly and constantly becoming obsolete. This is a world in which ideas are constantly subject to structural change, new tests and rethinking. Therefore, the main purpose of the school is to teach students not only to reproduce knowledge, but also to apply it to solve life problems. So, the development of critical thinking is an integral part of the modernization of the modern education in general and the optimization of English language learning in particular.
Analysis of recent research and publications Critical thinking was first introduced by Greek philosophers Many historians believe that the roots of critical thinking can be traced from Socrates' teaching practice and vision 2,500 years ago. He brilliantly revealed a probing questioning method that individuals could not logically justify their assertive claims to knowledge. Socrates' view of critical thinking, supported by Plato, was then applied by Descartes and was a theme in essays written by Montesquieu and John Locke. Many different definitions of critical thinking were suggested by various scholars such as Lipmen, Norris, Moore, Siegel. According to Elder and Paul critical thinking indicates the ability of people to take control on their own thinking and to develop appropriate criteria and standards for analyzing their own thinking [6]. Teaching critical thinking in the English classroom is important as it extends the learning experience of students, makes language learning more essential for them.

The purpose of the article. The main purpose of this work is to analyze effectiveness of critical thinking in training future English teachers and to define basic stages and techniques that help to form students' critical thinking.

Presenting main material. It is necessary to mention, that there are two points of view on (C) Rozumna T. S., 2020 
teaching critical thinking in the English classroom. Some teachers believe critical thinking is a result of schooling in students' native language, the others think that foreign language helps to develop critical thinking skills. Our idea is that well-designed communicative language classes help to develop these skills by comparing and contrasting cultures, discussing cause and effect of social events in the world, problems of current interest.

The literature on critical thinking - coming from psychology, education, and philosophy, agrees that critical thinking is multidimensional or polysemous. Moore claims that the variety of meanings may be discipline-based, meaning that psychology prefers certain aspects of critical thinking more so than history, which prefers others. Still, Moore was able to identify some common features which can define the concept more clearly.

According to Moore's research, critical thinking is:

- A judgment of whether something is good, bad, valid, or true;

- rational or reason-based skeptical thinking;

- productive thinking - not only challenging ideas but producing them - coming to conclusions about issues;

- carefully reading beyond a text's literal meaning;

- awareness of the entire process;

- ethical or activist - in other words, not neutral $[4$, p. 510$]$.

First, we have to understand that critical thinking is hard. Experimental research by Kuhn shows that a majority of people cannot demonstrate critical reasoning skills. That is, they cannot often justify their beliefs and opinions with evidence [1].

Van Gelder and Mulnix gave some practical advice how to teach critical thinking:

- Examples of critical thinking are not enough students need to engage in critical thinking.

- There needs to be deliberate practice to master the skill. This includes full concentration, exercises aimed at improving the skills, engaging in increasingly difficult exercises as easier ones are mastered, and guidance and feedback.

- The practice must be repetitive throughout a course.

- Students must practice transferring critical thinking skills to other contexts.

- Students must eventually become aware of the actual idea of critical thinking, including its terminology [5, p. 470].

Bloom's taxonomy is perhaps the most well-known example of critical thinking which consists of six-levels: 1. knowledge (specific facts); 2. comprehension (understanding of facts); 3. application (generalizing facts to other situations); 4. analysis (breaking problem down, recognizing connection between subparts); 5 . synthesis (combing separate elements to form a coherent whole); 6. evaluation (critically using information to make reasonable judgments. It is an orderly, visual representation and this is perhaps one reason why it has held educational weight since the late 50s. However, it has come under much scrutiny both for the way it has been organized and the way it has been employed. "Lower order skills" are not necessarily easier than "higher order skills" and vice-versa. In addition, these "lower" skills are often used in conjunction or even after using the "higher order skills". Notwithstanding, Bloom's taxonomy is an example of active learning in which, as one moves up the hierarchy, more and more areas of the brain become dynamically activated.

The formation of critical thinking skills consists of three stages:

1. Challenge. The purpose of it is the formation of personal interest for receiving information. Students learn to think and tell others (individually, in pairs, in group work) what they know about the chosen topic for discussion, in this way the acquired knowledge is realized and become the basis for learning new ones. The task of the teacher at this stage is to generalize the knowledge of students and to help them to determine the main goals for obtaining new ones. On this stage we can use such techniques as brainstorming, thin/thick questions or KWL chart. $\mathrm{K}-\mathrm{W}$-L charts are graphical organizers that help students organize information before, during, and after a lesson. They can be used to engage students in a new topic, enhance prior knowledge and monitor it. There are three questions in the chart: What do you Know about the topic? What do you Want to know? What have you Learned? Students answer the questions one by one, the last question gives a push to further search for new information yourself until the next lesson.

2. Comprehension. Students get acquainted with new information. At the same time, they must monitor their understanding and write down in the form of questions what they did not understand - in order to later fill in these "white spots". After reading the information, each student should tell which phrases or words helped him understand the information, and which confused. The main principle of the comprehension stage is that the teacher should give students the right to individual search for information with further group discussion and analysis. Here we can use such technique as six thinking hats. The "Six Hats" method is a psychological role play, which considers the same problem situation from 6 independent points of view. This allows you to form the most complete idea of the subject of discussion and at the logical and emotional levels to assess the advantages and disadvantages of this problem. Students form teams, each of which receives its own "hat". The color of the hat indicates the type of task: White hat - tell about the topic only in facts 
and figures; Yellow hat - think why ...; Black hat prove that ... ( within the theme); Red hat - think what emotional state can cause us this topic (or some of its key elements); Green hat - think how to use the theme or its elements to make our lives happier?; Blue hat - summarize the statements of all previous groups of hats. This technique also has the elements of reflection.

3. Reflection. Students should consider what they have learned and how to incorporate new concepts into their ideas; discuss how it changed their thoughts, visions, behavior. Here we can use such technique as "Cluster". There is the word in the center which is surrounded by other words or phrases connected with a theme. Students say everything they know using brainstorming. It can be not only clear facts, but also associations or creative perceptions. Then all this information is grouped, classified, categorized and formalized graphically in a certain scheme by students.

We can also use such technique as "Cinquain". It is a short unrhymed poem of 5 lines. The technique of this poem is ideal for the development of figurative thinking, concentration of knowledge, rethinking the information obtained, expressing their position on the topic, as well as for learning new concepts in a foreign language. The rules of cinquain are as follows: the first line - 1 word -main topic or object of discussion (noun or pronoun); the second line - 2 words describing the properties, signs, characteristics of the object (adjectives, verbs); the third line -3 words describing actions, characteristic of the object (verbs, adjectives); the fourth line - a phrase of 4 words, in which the author expresses a personal attitude to the topic; the fifth line - a word-summary, a key characteristic or a new interpretation of the object.

In order to activate students' critical thinking skills, English teachers need to present alternatives, different ways of interpreting texts and different conceptions of the world. The importance of thinking in today's education requires the main concept of critical thinking in which there is always more than one way to see things and that it is always up to the individual to judge just where the truth lies on any given issue [3].

It is also should mention, that critical thinking can be developed at any part of the lesson. As we know, there are four basic activities at the English lesson. They are listening, reading, speaking and writing. Listening and reading are the receptive skills because learners do not need to produce language, they receive and understand it. These skills are sometimes known as passive skills. The productive skills are speaking and writing because learners are applying these skills in a need to produce language. They are also known as active skills. For example, the technique "Corners" help to develop critical thinking using all these four skills.
"Corners" is used to teach students selfdetermination and advocacy. It got its name from the form of conducting - students formulate different points of view on the topic and differ in different corners to find relevant arguments. Teacher needs to organize this process so that students independently identify controversial issues and the direction of the discussion, they choose the corners themselves. Texts, articles, and life events that have a multifaceted worldview and relate to everyday perceptions, patterns of behavior, social and environmental issues, collective myths, and prejudices are best suited for such a discussion. There are several stages of this technique:

- Acquaintance with the text. The teacher should choose a text that from the beginning can lead to many different interpretations.

- Students form their key ideas about the information obtained and discuss the text in pairs or small groups. The task may sound different, for example: "Write down your opinion about what you have read", "Evaluate the behavior of the heroes", "Explain why this could happen", "Offer your solution".

- In each group, one student must be an analyst whose task is to identify opposing points of view. The teacher also sets him a confidential task - to find out how the members of each group choose their point of view, which arguments are used. So analysts move between teams and make personal notes.

- The groups present in front of everyone the main ideas of their discussion. As usual, there are several different points of view, which were repeated in different groups. The teacher helps children to formulate various key positions by which children are grouped into new teams and diverge "in the corners". Analysts are a separate group. Children whose point of view does not coincide with any of the corners, have a choice: to join the most appropriate "corner" or to join the group of analysts.

- Then each of the groups together seeks arguments and prepares to defend their point of view. Speakers are also selected in the teams.

- At the same time, a group of analysts develops criteria for evaluating the performances of teams. The teacher can help them.

- Speakers from the teams represent their key idea and its arguments. After that, analysts with the help of the teacher should evaluate the speeches of the groups according to the criteria they have identified (maximum number of criteria is 5). Priority should be given not only to the team that most clearly argued the point of view (with theories, facts, data and examples), but also to the group that was able to summarize the views of other teams and took them into account in their speech.

- The result of the evaluation should be announced as tolerantly as possible, with accentuated positive moments in each speech. Analysts should be warned about this in advance. 
As we see, doing this exercise involves reading, listening and speaking. As for the writing, it can be a homework. For example, write for and against essay on the topic or a certain aspect of the topic.

Conclusions and suggestions. The development of critical thinking is an indisputable condition of social progress, a factor in increasing motivation for self-realization. Introduction of critical thinking provides a transition from learning, focused mainly on memorization, to learning aimed at developing independent conscious thinking of students, helps to prepare students for life in an information society, choose the truth among the constant flow of information, critically check the information, cooperate with others.

Critical thinking creates additional motivation for learning. Students learn the material better because it is interesting to them. They learn to apply new knowledge based on previously learned material; they develop the ability to act and make decisions independently or as a team and resolve conflicts; search, compose and apply new information from a variety of sources, using modern technology to perform specific tasks. Students more confidently perform complex mental operations; answer high-level questions; are able to interpret the text, all these help in learning English and prepares future
English teachers to their profession. The realization of critical thinking skills in English language teaching improves students' English competence, creates lively learning atmosphere.

\section{References:}

1. Kuhn D. The skills of argument. Cambridge, M.A. : Cambridge Press. 1991. 336 p.

2. Lipman M. Thinking in education. New York : Cambridge University Press. 2003. 316 p.

3. Mason, J. and Washington, P. The Future of Thinking. London and New York : Routledge. 1992. $134 \mathrm{p}$.

4. Moore T. Critical thinking: seven definitions in search of a concept. Studies in Higher Education. 2013. № 38(4). P. 506-522.

5. Mulnix, J.W. Thinking critically about critical thinking. Educational Philosophy and Theory. 2012. № 44(5). P. 464-479.

6. Paul, R.W. \& Elder L. The Miniature Guide to Critical Thinking Concepts \& Tools ( $6^{\text {th }}$ ed.) Dillon Beach, CA : The Foundation for Critical Thinking, 2009. $21 \mathrm{p}$.

7. Siegal H. Educating reason: Rationality, critical thinking, and education. New York : Routledge. 1988. $191 \mathrm{p}$.

\section{Розумна Т. С. Навчання критичного мислення майбутніх учителів англійської мови}

У статті розглядаються питання навчання критичного мислення майбутніх учителів англійської мови. Основною метою роботи є аналіз ефрективності критичного мислення в навчанні майбутніх учителів англійської мови та визначення основних етапів та прийомів, які допомагають формувати критичне мислення студентів. $€$ дві точки зору на викладання критичного мислення на заняттях з англійської мови. Одні викладачі вважають, що критичне мислення є результатом навчання рідної мови студентів, інші вважають, що іноземна мова допомагає розвивати навички критичного мислення. Ідея автора полягає в тому, що добре розроблені комунікативні мовні заняття допомагають розвивати ці вміння шляхом порівняння та протиставлення культур, обговорення причини та наслідків соціальних подій у світі.

Формування навичок критичного мислення складається з трьох етапів: виклик, осмислення, рефрлексія. На кожному етапі можна використовувати різні прийоми. На першому етапі можуть використовуватися такі прийоми, як мозковий итурм, товсті/тонкі питання або діаграма KWL. На етапі осмислення автор використовує метод "Шість капелюхів», а на рефрлексії майбутні вчителі англійської мови пишуть вірші «Сінквейн». Щоб активізувати навички критичного мислення студентів, викладачам англійської мови необхідно представити альтернативи, різні способи інтерпретації текстів та різні уявлення про світ. Варто також зазначити, що критичне мислення можна розвивати в будь-якій частині уроку. Наприклад, техніка «Кути» допомагає розвивати критичне мислення, використовуючи всі чотири основні навички (читання, аудіювання, письмо та говоріння).

Введення критичного мислення забезпечує перехід від навчання, орієнтованого головним чином на запам'ятовування, до навчання, спрямованого на розвиток самостійного свідомого мислення учнів, допомагає підготувати учнів до життя в інформаційному суспільстві, вибрати істину серед постійного потоку інфоормації, критично перевірити інфоормацію, співпрацювати з іншими.

Ключові слова: критичне мислення, майбутні вчителі англійської мови, інтерактивні методи навчання, етапи, прийоми. 